\title{
PERIODICITY OF EXPOSURE OF HYDROPONIC LETTUCE PLANTS TO NUTRIENT SOLUTION ${ }^{1}$
}

\author{
CLEITON DALASTRA ${ }^{2}$, MARCELO CARVALHO MINHOTO TEIXEIRA FILHO², PABLO FORLAN VARGAS ${ }^{3 *}$
}

\begin{abstract}
A balanced periodicity of the nutrient solution flow is essential for better agronomic performances and low production costs in hydroponic systems. Thus, the objective of this work was to evaluate the effect of periodicity of exposure of lettuce plants to the nutrient solution in an NFT hydroponic system on the production, nutrition, and profitability of this crop. The experiment was conducted in a randomized block design with five replications. The treatments consisted of four periodicities of exposure of lettuce plants to the nutrient solution, consisting of intervals of 60,30, and 15 minutes between pumping periods of 15 minutes; and uninterrupted flow of the nutrient solution. The plants were harvested at 30 days after transplanting, and 15 lettuce plants of each experimental plot were used to determine total fresh weight; root fresh weight; shoot freshweight; and contents of $\mathrm{N}, \mathrm{P}, \mathrm{K}, \mathrm{Ca}, \mathrm{Mg}, \mathrm{S}, \mathrm{B}, \mathrm{Cu}, \mathrm{Fe}, \mathrm{Mn}$, and $\mathrm{Zn}$ in shoots, roots, and in the diagnostic leaf; accumulation of these nutrients in shoots and roots; and nitrate and ammonium contents in plant shoot. The highest production and profitability of lettuce were found using uninterrupted nutrient solution flow, which provided higher shoot and root nutrient contents to plants, and resulted in a better nutrient use efficiency.
\end{abstract}

Keywords: Lactuca sativa L. Leaf nutrient concentration. Diagnostic leaf. Profitability. NFT hydroponic system. Intermittent flow of nutrient solution.

\section{PERIODICIDADE DE EXPOSIÇÃO DA ALFACE AMERICANA À SOLUÇÃO HIDROPÔNICA}

RESUMO - O equilíbrio entre o tempo de alternância do fluxo da solução nutritiva visando o melhor desempenho agronômico e menor custo de produção é de fundamental importância no cultivo hidropônico. Dessa forma, o objetivo deste trabalho foi avaliar efeito da periodicidade de exposição à solução nutritiva em sistema hidropônico NFT, na produção, nutrição e rentabilidade de alface americana. O delineamento experimental foi em blocos casualizados, com cinco repetições. Os tratamentos foram quatro combinações de intermitência de exposição da solução nutritiva em intervalos de bombeamento / intervalo de ausência de bombeamento, sendo estes em minutos: 15/60;15/30; 15/15 e FI (Fluxo ininterrupto da solução nutritiva). A colheita foi realizada aos 30 DAT sendo massa fresca total, do sistema radicular e da parte aérea das 15 plantas de alface de cada uma das parcelas experimentais. Também foram avaliados os teores de N, P, K, Ca, Mg, S, B, $\mathrm{Cu}, \mathrm{Fe}, \mathrm{Mn}$ e $\mathrm{Zn}$ na parte aérea, raízes e na folha diagnose da alface e calculados os acúmulos dos mesmos de nutrientes na parte aérea e raízes das plantas. Ademais, determinou-se os teores de nitrato e amônio na parte aérea da alface. A maior produção e rentabilidade de alface americana foi obtida com fluxo ininterrupto (FI) da solução nutritiva, devido ao maior acúmulo de nutrientes na parte aérea e raiz e eficiência de utilização de nutrientes.

Palavras-chave: Lactuca sativa L. Concentração de nutrientes foliar. Diagnose foliar. Lucratividade. Sistema hidropônico NFT. Alternância do fluxo da solução nutritiva.

\footnotetext{
${ }^{*}$ Corresponding author

${ }^{1}$ Received for publication in $03 / 28 / 2019$; accepted in $11 / 04 / 2019$.

Paper extracted from the doctoral thesis of the first author.

${ }^{2}$ Department of Plant Protection, Rural Engineering and Soils, Universidade Estadual Paulista, Ilha Solteira, SP, Brazil; sauems@gmail.com - ORCID: 0000-0003-4107-843X, mcm.teixeira-filho@unesp.br - ORCID: 0000-0003-2303-3465.

${ }^{3}$ Department of Agronomy, Universidade Estadual Paulista, Registro, SP, Brazil; pablo.vargas@unesp.br - ORCID: 0000-0002-57186403 .
} 


\section{INTRODUCTION}

Lettuce (Lactuca sativa L.) is the most market and consumed leafy vegetable in Brazil because it can be produced throughout the year, has culinary characteristics, and good acceptance by consumers (ABCSEM, 2017). Its national production for the wholesale market in 2016 was 105.207 Mg, generating more than BRL (R\$) 288 million (CONAB, 2017), and it is estimated that the retail sales reached BRL (R\$) 8 billion, with a production higher than 1.5 million $\mathrm{Mg}$ (ABCSEM, 2017). These data were from lettuces produced using two growing systems: with soil or without soil (hydroponics).

Hydroponics is an intense production method for vegetables and an alternative for the supplying of an increasing demand for these foods due to the lack of soils with adequate physical, chemical, and sanitary characteristics for growing these crops (LEIVA ESPINOZA, 2019).

Hydroponics is an alternative for the growing of crops in soils, presenting advantages to consumers, producers, and environment, such as: reduced crop cycle, high yield, and better uses of water and agricultural inputs (PAULUS et al., 2012).

This technique consists of growing plants without any contact with soil, which receive a nutrient solution made of nutrients dissolved in water; thus, this solution can supply all the essential elements that plants need to grow.

The nutrient film technique (NFT) is one of the most common technique in hydroponics, which consists of a circulating system that supplies water containing nutrients to plant roots (MOHAMMED, 2018). NFT hydroponic system is largely used in Brazil, mainly for lettuce crops (LUZ et al., 2017).

In this system, the water containing nutrient solution flows through growing channels where the plant roots are to irrigate and supply oxygen and nutrients to plants (MARTINS et al., 2009). The definition of intermittent exposure of plants to the nutrient solution is mainly dependent on environmental characteristics, such as solar radiation and air temperature and humidity, and plant physiology.

The intermittence of the nutrient solution flow in the growing channels should be based on the plant water demand. The absence of supply of nutrient solution to plants decreases water availability and will cause water deficit, increase in leaf temperature, and stomatal closure, decreasing photosynthesis and, consequently, the crop production, since the plants will adequate their photosynthesis to the water availability conditions.

However, a nutrient solution that circulates longer than necessary, without improving the crop performance, affects directly the electrical energy consumption, which can reach $19.7 \%$ of the total cost (LONDERO; AITA, 2000). Therefore, a balanced periodicity of the nutrient solution flow is essential for better agronomic performances and low production costs in hydroponic systems, which is a factor sometimes underestimated by producers and researches.

Thus, the objective of this work was to evaluate the effect of periodicity of exposure of lettuce plants to the nutrient solution in an NFT hydroponic system on the production, nutrition, and profitability of lettuce.

\section{MATERIAL AND METHODS}

The experiment was conducted between May and June 2017 in a commercial hydroponic crop under a $25 \%$ red shade screen, in Aparecida do Taboado, MS, Brazil (20³'58"S; 51 ${ }^{\circ} 10^{\prime} 54^{\prime \prime} \mathrm{W}$; and altitude of $379 \mathrm{~m})$. The climate of the region presented air temperatures of $11{ }^{\circ} \mathrm{C}$ to $25^{\circ} \mathrm{C}$ and relative air humidity of $50 \%$ to $90 \%$ during the experiment period (Figure 1).

A randomized experimental block design with five replications was used. The treatments consisted of four periodicities of exposure of lettuce plants to the nutrient solution, consisting of intervals of $60(15 / 60), 30(15 / 30)$, and $15(15 / 15)$ minutes between pumping periods of 15 minutes, and uninterrupted flow of the nutrient solution. Each experimental plot was composed of 15 lettuce plants, and the evaluation area consisted of 9 plants.

The experimental units were installed on 7 meter long individual benches with $10 \%$ slope. Growing channels were made of PVC tubes $(8 \mathrm{~cm}$ width and $4 \mathrm{~cm}$ height) with a rectangular session, containing holes at the top for placing the plants every 25 centimeters. Each bench consisted of 7 growing channels spaced $20 \mathrm{~cm}$ apart, an individual pumping system, and a $310-\mathrm{L}$ tank that was kept at least $95 \%$ full. 


\section{Driving period}

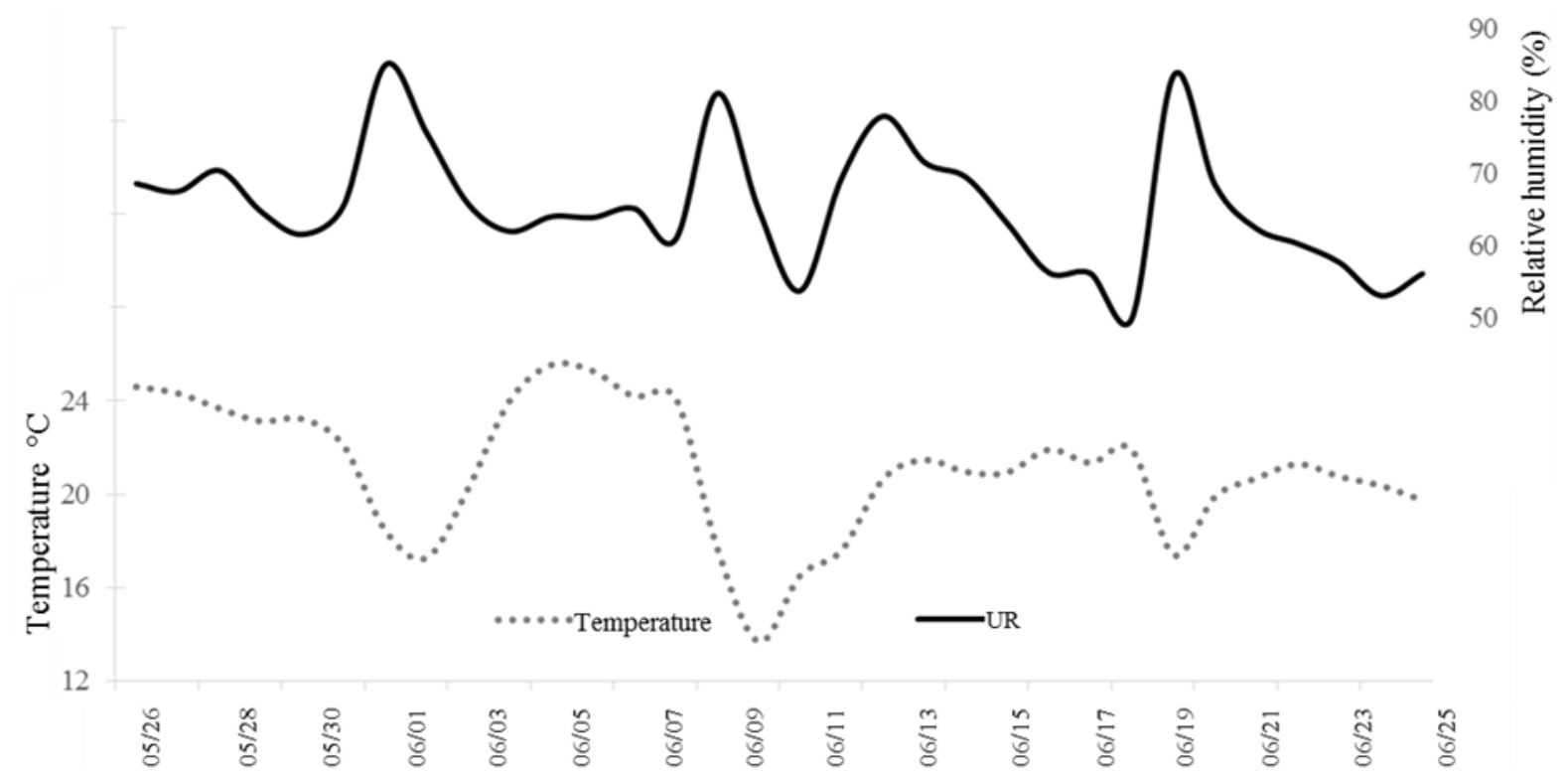

Figure 1. Air temperature and relative air humidity during the experiment period. Aparecida do Taboado, MS, Brazil, 2018.

The Betty lettuce cultivar (Horticeres ${ }^{\circledR}$ ) was used, which is of the Americana group. It is a tall plant with high volume of large and thick leaves, having a good head protection, and presents good tolerance to early bolting. Its average cycle is 70 days when growing in soils, however, its presents early cycle when growing in hydroponic systems; its ideal plant population is between 80 and 160 thousand plants per hectare (Horticeres, 2019).

The lettuce seedlings were produced in phenolic foams and kept for 12 days in a nursery covered with $25 \%$ red shade screen; subsequently, they were transplanted to the growing channels on the benches where they were kept for 22 days until the harvest.

A nutrient solution was pumped using a closed-circuit system with flow rate of $1 \mathrm{~L}$ per minute through each growing channel, according to the intermittence of each treatment. The nutrient solution used consisted of diluted concentrate fertilizers (PlenanFerti PM1 ${ }^{\circledR}$ and PlenanFerti PM2 ${ }^{@)}$ ) at $1.23 \mathrm{~g} \mathrm{~mL}^{-1}$, which were supplied at equal proportion; the nutrient concentrations in the nutrient solution were $\left(\mathrm{g} \mathrm{L}^{-1}\right): 77.65$ of $\mathrm{N}, 15.95$ of $\mathrm{P}$, 75.26 of K, 23.39 of S, 41.60 of $\mathrm{Ca}, 17.82$ of $\mathrm{Mg}$, 0.27 of B, 0.08 of $\mathrm{Cu}, 1.09$ of $\mathrm{Fe}, 0.29$ of Mn, 0.05 of Mo, 0.06 of $\mathrm{Ni}$, and 0.11 of $\mathrm{Zn}$. Initially, $0.3 \mathrm{~L}$ of each fertilizer were used for each $300 \mathrm{~L}$ of solution, however, the replenishment of salts in the nutrient solution varied according to the plant demand in each treatment, based on the electrical conductivity (EC) of the solution. EC and $\mathrm{pH}$ were measured on all plants every morning and corrected when necessary by adding nutrients to the nutrient solution. The EC of the solution was kept at $0.9 \mathrm{dSm}^{-}$ ${ }^{1}$ for the seedlings; in the first 10 days after transplanting (DAT) the EC was kept at $1.2 \mathrm{dSm}^{-1}$; and after 10 DAT up to the end of the crop cycle, the EC was kept at $1.6 \mathrm{dSm}^{-1}$.

The plants were harvested at 30 DAT with a 344-degree-day thermal accumulation, and total fresh weight, root fresh weight, and shoot fresh weight of the 15 lettuce plants of each experimental plot were evaluated. Subsequently, these plants were dried in a forced-air circulation oven at $60{ }^{\circ} \mathrm{C}$ for 72 hours for determination of their total dry weight, root dry weight, and shoot dry weight.

Then, these plant materials were ground in a Wiley mill for determination of $\mathrm{N}, \mathrm{P}, \mathrm{K}, \mathrm{Ca}, \mathrm{Mg}, \mathrm{S}$, $\mathrm{B}, \mathrm{Cu}, \mathrm{Fe}, \mathrm{Mn}$, and $\mathrm{Zn}$ contents in shoots, roots, and in the diagnostic leaf young developed leaves (TRANI; RAIJ, 1997) according to the methodology of Malavolta, Vitti and Oliveira (1997). The nutrient accumulation in shoots and roots of these plants were determined based on their respective dry matters and contents of the evaluated nutrients. Nitrate and ammonium contents in plant shoots were determined according to the methodology described by Tedesco, Volkweiss and Bohnen (1985).

The nutrient use efficiency (NUE) of each treatment was obtained according to Equation 1 (SIDDIQI; GLASS, 1981).

Equation 1

$\mathrm{NUE}=(\text { total dry weight of the plant })^{2} /$ (total nutrient accumulation in the plant)

The data were subjected to analysis of variance. The means of the treatments (periodicity of exposure of plants to the nutrient solution) were compared by the Tukey's test at 5\% significance, considering the need to find the periodicity that aggregated the highest number of variables of productive interest, not individual results of optimal 
periodicity for each variable. The SISVAR program was used for the analyses.

An economic analysis was done using spreadsheets to calculate the production cost, according the methodology adapted by Matsunaga and Toledo (1976), in which the variable cost is only the direct disbursement, and the investment, depreciation, and opportunity cost of the invested capital are a single fixed cost, considering a cost structure based on fixed cost.

\section{RESULTS AND DISCUSSION}

The lettuce plants subjected to uninterrupted nutrient solution flow (UF) presented higher fresh and dry weights of shoots and roots (Figure 2), followed by those subjected to the treatments with nutrient solution flow periodicities of $15 / 60$ and $15 / 15$ minutes, which presented differences only for shoot dry weight.

The results of the lettuce plants in the treatments $15 / 30,15 / 15$, and UF is directly related to the evolution of the NFT hydroponic system regarding the growing channel slope, which was initially proposed as $3 \%$ to $4 \%$; but the current recommendation is usually $10 \%$. This change in the system allows the nutrient solution to flow at a higher speed and turbulence, generating better cooling and transport of dissolved oxygen to the submerse roots. Moreover, considering an adequate flow rate, this change indicates no need for intermittent flow of the nutrient solution under the conditions studied in the present experiment.
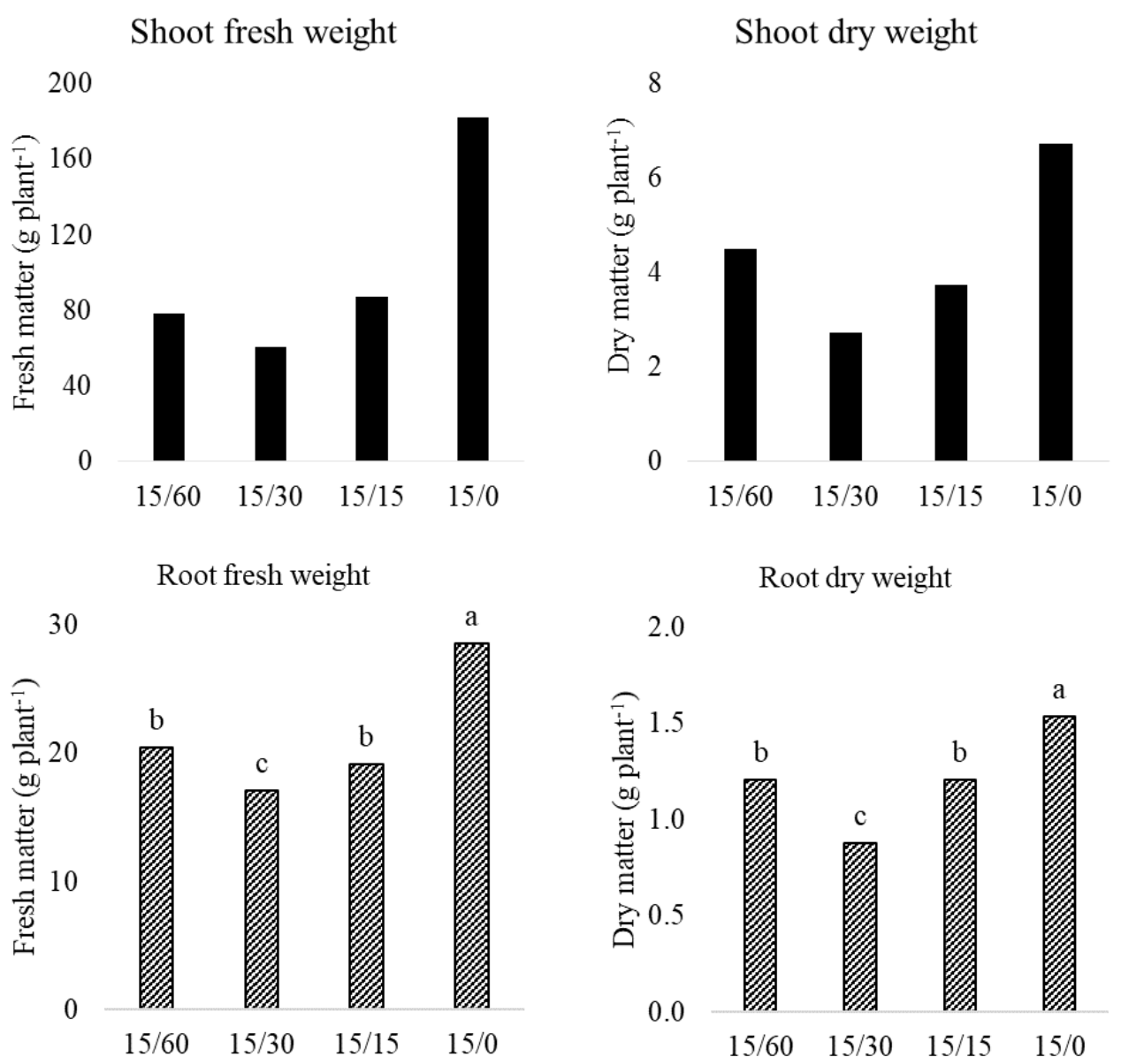

Figure 2. Shoot and root fresh and dry weights $\left(g_{\text {plant }}{ }^{-1}\right)$ of lettuce plants grown under different periodicities of exposure to the nutrient solution in a hydroponic system. Aparecida do Taboado, MS, Brazil, 2018. 
The intermittence of nutrient solution flow in NFT hydroponic systems contributes to the respiration and consequent oxygenation of the root system that was submerse in the nutrient solution. However, it causes collateral damages to plants, since the absence of nutrient solution flow can prevent the cooling of the tubes exposed to solar radiation, increasing the temperature inside these tubes, which causes the death of roots (CASAROLI et al., 2003).

The dry weights found in the treatment $15 / 60$ minutes can be explained, since a severely compromised root system development hinders water and nutrient supply to plants and decreases significantly their development. Under such conditions, these plants emit adventitious roots for their recovery, thus avoiding their death and ensuring the supply of the nutrient demand of their aerial part
(PRADO; CECÍLIO FILHO, 2016), but with an unnecessary energy expenditure.

The use of intervals of 15 to 45 minutes between pumping periods of 45 minutes altered the dry weight of the root system in an experiment conducted in Rio Grande do Sul, Brazil, with the highest values between 0.76 and 0.83 g per plant, and the treatment $45 / 45$ minutes showed the best result (LUZ et al., 2008). Similar results were found for lettuce plants of the cultivar Regina that presented total dry weight of 9.7 g per plant during the spring (BACKES et al., 2003) and 7.1 g per plant during the autumn (CARON et al., 2003).

UF stood out as the only treatment that presented high or adequate nutrient contents in the diagnostic leaf, according to the sufficiency range proposed by Trani and Raij (1997) (Table 1).

Table 1. Nutrient contents in the diagnostic leaf of lettuce plants subjected to different periodicities of exposure to nutrient solution in a hydroponic system.

\begin{tabular}{|c|c|c|c|c|c|}
\hline & $15 / 60$ minutes & $15 / 30$ minutes & $15 / 15$ minutes & UF \\
\hline & & Leaf content & Leaf content & Leaf content & Leaf content \\
\hline \multicolumn{2}{|l|}{$\mathrm{N}$} & $32.67 \mathrm{~A}$ & $38.33 \mathrm{~A}$ & $41.3 \mathrm{~A}$ & $40.93 \mathrm{~A}$ \\
\hline \multicolumn{2}{|l|}{$\mathrm{P}$} & $5.13 \mathrm{~A}$ & $5.97 \mathrm{~A}$ & $6.70 \mathrm{~A}$ & $6.83 \mathrm{~A}$ \\
\hline K & Top & $36.27 \mathrm{~L}$ & $41.17 \mathrm{~L}$ & $42.73 \mathrm{~L}$ & $50.9 \mathrm{~A}$ \\
\hline \multicolumn{2}{|l|}{$\mathrm{Ca}$} & $6.2 \mathrm{~L}$ & $8.57 \mathrm{~L}$ & $7.87 \mathrm{~L}$ & $15.3 \mathrm{~A}$ \\
\hline \multicolumn{2}{|l|}{$\mathrm{Mg}$} & $3.23 \mathrm{~L}$ & $4.57 \mathrm{~A}$ & $4.43 \mathrm{~A}$ & $6.43 \mathrm{H}$ \\
\hline \multicolumn{2}{|l|}{ S } & - - 1.77_A & - - 2.10A & - - - 2.37 A & - - 2.17 A \\
\hline \multicolumn{2}{|l|}{ B } & $39.67 \mathrm{~A}$ & $40.00 \mathrm{~A}$ & $42.67 \mathrm{~A}$ & $43.00 \mathrm{~A}$ \\
\hline & $T^{\prime}$ & $13.33 \mathrm{~A}$ & $15.00 \mathrm{~A}$ & $23.33 \mathrm{H}$ & $23.33 \mathrm{H}$ \\
\hline & 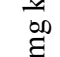 & $194.33 \mathrm{H}$ & $223.33 \mathrm{H}$ & $198.33 \mathrm{H}$ & $327.67 \mathrm{H}$ \\
\hline \multicolumn{2}{|l|}{$\mathrm{Mn}$} & $65.67 \mathrm{~A}$ & $94.67 \mathrm{~A}$ & $100.33 \mathrm{~A}$ & $173.67 \mathrm{H}$ \\
\hline \multicolumn{2}{|l|}{$\mathrm{Zn}$} & $69.00 \mathrm{~A}$ & $108.00 \mathrm{H}$ & $117.33 \mathrm{H}$ & $215.00 \mathrm{H}$ \\
\hline
\end{tabular}

The nutrient contents in the diagnostic leaf of lettuce plants were interpreted based on Trani and Raij (1997): high $(\mathrm{H})$, adequate $(\mathrm{A})$, and low $(\mathrm{L}) .15 / 60,15 / 30$, and 15/15 minutes = times of exposure of the plants to the nutrient solution (flow/absence of flow) applied through a rectangular 7 meters long PVC tubes with $10 \%$ slope, at flow rate of $1 \mathrm{~L}$ per minute; $\mathrm{UF}=$ uninterrupted flow of nutrient solution.

The others treatments had similar deficiency of $\mathrm{K}$ and $\mathrm{Ca}$; these low contents of these nutrients can be due to an inefficient absorption of the nutrient solution because of damaged root systems. However, $\mathrm{K}$ and $\mathrm{Ca}$ deficiency symptoms were not found in the plants, which characterize these low $\mathrm{K}$ and $\mathrm{Ca}$ contents as a moderate deficiency, or even as a low requirement of this lettuce cultivar for these exchangeable bases.

The nutrient solution in hydroponic systems is the only source of water and minerals to plants, thus, nutrition and water stability are reached by plants through absorptions of this substrate; and the plant physiology is the responsible for balancing nutrient and water uptakes to maintain the water potential of the plant shoot or balancing the water volume that is absorbed together with the nutrients (TAIZ; ZEIGER, 2004).

Thus, a higher absorption of the nutrient solution by better-performance plants contributes to a high micronutrient contents in plant tissues; this was denoted by the high micronutrient contents found in the plants subjected to uninterrupted flow of the nutrient solution, which decreased as the intervals between pumping periods were increased up to 60 minutes.

$\mathrm{N}, \mathrm{Mg}, \mathrm{S}, \mathrm{Cu}$, and $\mathrm{B}$ contents in the plant shoot were similar in all treatments evaluated. The 
highest $\mathrm{P}, \mathrm{Ca}, \mathrm{Mn}$, and $\mathrm{Zn}$ contents were found in plants in the treatment UF, while the highest $\mathrm{K}$ and Fe contents were found in plants in the treatment
$15 / 30$, but with no significant differences between the treatments (Table 2).

Table 2. Content and accumulation of nutrients in shoot and root systems of lettuce plants subjected to different periodicities of exposure to nutrient solution in a hydroponic system.

\begin{tabular}{|c|c|c|c|c|c|c|c|c|}
\hline & $15 / 60$ & $15 / 30$ & $15 / 15$ & UF & $15 / 60$ & $16 / 30$ & $15 / 15$ & UF \\
\hline & \multicolumn{4}{|c|}{ Content in plant shoot system $\left(\mathrm{g} \mathrm{kg}^{-1}\right)$} & \multicolumn{4}{|c|}{ Accumulation in plant shoot system $\left(\mathrm{g}_{\text {plant }}{ }^{-1}\right)$} \\
\hline $\mathrm{N}$ & $37.87 \mathrm{a}$ & $39.07 \mathrm{a}$ & $37.67 \mathrm{a}$ & $37.33 \mathrm{a}$ & $0.15 b$ & $0.11 \mathrm{c}$ & $0.14 \mathrm{~B}$ & $0.25 \mathrm{a}$ \\
\hline $\mathrm{NO}_{3}^{-}$ & $0.49 \mathrm{a}$ & $0.68 \mathrm{a}$ & $0.24 b$ & $0.007 \mathrm{c}$ & $0.002 \mathrm{a}$ & $0.002 \mathrm{a}$ & $0.001 \mathrm{~B}$ & $0.0004 \mathrm{c}$ \\
\hline $\mathrm{NH}_{4}^{+}$ & $0.76 \mathrm{a}$ & $0.41 \mathrm{~b}$ & $0.68 \mathrm{a}$ & $0.64 \mathrm{a}$ & $0.003 b$ & $0.002 \mathrm{c}$ & $0.002 \mathrm{C}$ & $0.004 \mathrm{a}$ \\
\hline $\mathrm{P}$ & $6.13 b$ & $6.53 b$ & $7.60 \mathrm{~b}$ & $10.47 \mathrm{a}$ & $0.03 b$ & $0.02 b$ & $0.03 \mathrm{~B}$ & $0.07 \mathrm{a}$ \\
\hline K & $66.60 \mathrm{ab}$ & $74.60 \mathrm{a}$ & $42.57 \mathrm{~b}$ & $41.47 \mathrm{~b}$ & $0.30 \mathrm{a}$ & $0.21 \mathrm{~b}$ & $0.16 \mathrm{C}$ & $0.28 \mathrm{a}$ \\
\hline $\mathrm{Ca}$ & $12.10 \mathrm{~b}$ & $16.57 \mathrm{ab}$ & $14.97 b$ & $20.97 \mathrm{a}$ & $0.05 b$ & $0.05 b$ & $0.06 \mathrm{~B}$ & $0.14 \mathrm{a}$ \\
\hline $\mathrm{Mg}$ & $6.90 \mathrm{a}$ & $7.23 \mathrm{a}$ & $7.10 \mathrm{a}$ & $7.43 \mathrm{a}$ & $0.03 b$ & $0.02 b$ & $0.03 \mathrm{~B}$ & $0.05 \mathrm{a}$ \\
\hline S & $2.37 \mathrm{a}$ & $2.47 \mathrm{a}$ & $2.37 \mathrm{a}$ & $2.80 \mathrm{a}$ & $0.01 b$ & $0.01 \mathrm{~b}$ & $0.01 \mathrm{~B}$ & $0.02 \mathrm{a}$ \\
\hline \multicolumn{5}{|c|}{ Content in plant shoot system $\left(\mathrm{mg} \mathrm{kg}^{-1}\right)$} & \multicolumn{4}{|c|}{ Accumulation in plant shoot system $\left(\mathrm{mg} \mathrm{plant}^{-1}\right)$} \\
\hline B & $38.33 \mathrm{a}$ & $41.67 \mathrm{a}$ & $49.00 \mathrm{a}$ & $37.33 \mathrm{a}$ & $0.17 \mathrm{~b}$ & $0.12 \mathrm{c}$ & $0.18 \mathrm{~B}$ & $0.25 \mathrm{a}$ \\
\hline $\mathrm{Cu}$ & $21.67 \mathrm{a}$ & $21.00 \mathrm{a}$ & $26.00 \mathrm{a}$ & $25.00 \mathrm{a}$ & $0.10 \mathrm{~b}$ & $0.06 \mathrm{c}$ & $0.10 \mathrm{~b}$ & $0.17 \mathrm{a}$ \\
\hline $\mathrm{Fe}$ & $520.67 b$ & $659.00 \mathrm{a}$ & $562.00 \mathrm{ab}$ & $566.67 \mathrm{ab}$ & $2.35 b$ & $1.80 \mathrm{c}$ & $2.12 \mathrm{~d}$ & $3.79 \mathrm{a}$ \\
\hline $\mathrm{Mn}$ & $116.00 \mathrm{c}$ & $151.00 \mathrm{~b}$ & $152.00 \mathrm{~b}$ & $229.00 \mathrm{a}$ & $0.52 b$ & $0.41 b$ & $0.58 \mathrm{~b}$ & $1.54 \mathrm{a}$ \\
\hline $\mathrm{Zn}$ & $108.33 b$ & $161.33 \mathrm{ab}$ & $213.33 \mathrm{ab}$ & $274.67 \mathrm{a}$ & $0.49 \mathrm{c}$ & $0.44 \mathrm{c}$ & $0.83 b$ & $1.84 \mathrm{a}$ \\
\hline \multicolumn{5}{|c|}{ Content in plant root system $\left(\mathrm{g} \mathrm{kg}^{-1}\right)$} & \multicolumn{4}{|c|}{ Accumulation in plant root system $\left(\mathrm{g}_{\text {plant }}{ }^{-1}\right)$} \\
\hline $\mathrm{N}$ & $45.00 \mathrm{a}$ & $44.60 \mathrm{a}$ & $47.23 \mathrm{a}$ & $46.90 \mathrm{a}$ & $0.054 \mathrm{~b}$ & $0.039 b$ & $0.057 \mathrm{a}$ & $0.072 \mathrm{a}$ \\
\hline $\mathrm{P}$ & $14.90 \mathrm{~b}$ & $17.33 \mathrm{ab}$ & $16.96 \mathrm{ab}$ & $19.40 \mathrm{a}$ & $0.018 \mathrm{~b}$ & $0.015 \mathrm{c}$ & $0.020 \mathrm{~b}$ & $0.030 \mathrm{a}$ \\
\hline K & $23.86 \mathrm{a}$ & $21.56 \mathrm{a}$ & $25.03 \mathrm{a}$ & $24.76 \mathrm{a}$ & $0.029 b$ & $0.019 \mathrm{c}$ & $0.030 \mathrm{~b}$ & $0.038 \mathrm{a}$ \\
\hline $\mathrm{Ca}$ & $6.30 \mathrm{a}$ & $5.16 \mathrm{~b}$ & $5.30 \mathrm{~b}$ & $5.33 \mathrm{a}$ & $0.008 \mathrm{a}$ & $0.005 b$ & $0.006 \mathrm{~b}$ & $0.008 \mathrm{a}$ \\
\hline $\mathrm{Mg}$ & $2.36 \mathrm{a}$ & $2.06 \mathrm{a}$ & $2.10 \mathrm{a}$ & $2.03 \mathrm{a}$ & $0.003 b$ & $0.002 b$ & $0.003 b$ & $0.003 \mathrm{a}$ \\
\hline S & $9.70 \mathrm{a}$ & $11.16 \mathrm{a}$ & $10.10 \mathrm{a}$ & $10.23 \mathrm{a}$ & $0.012 b$ & $0.010 \mathrm{~b}$ & $0.012 b$ & $0.016 \mathrm{a}$ \\
\hline \multicolumn{5}{|c|}{ Content in plant root system $\left(\mathrm{mg} \mathrm{kg}^{-1}\right)$} & \multicolumn{4}{|c|}{ Accumulation in plant root system (mg plant $\left.{ }^{-1}\right)$} \\
\hline B & $19.33 \mathrm{a}$ & $25.66 \mathrm{a}$ & $28.33 \mathrm{a}$ & $26.66 \mathrm{a}$ & $0.023 b$ & $0.022 b$ & $0.036 \mathrm{a}$ & $0.041 \mathrm{a}$ \\
\hline $\mathrm{Cu}$ & $186.66 \mathrm{~b}$ & $220.66 b$ & $224.33 b$ & $286.00 \mathrm{a}$ & $0.226 \mathrm{c}$ & $0.193 \mathrm{c}$ & $0.270 \mathrm{~b}$ & $0.438 \mathrm{a}$ \\
\hline $\mathrm{Fe}$ & $6768.00 \mathrm{c}$ & $1047.00 \mathrm{~b}$ & $7864.00 \mathrm{bc}$ & $14507 \mathrm{a}$ & $8.166 \mathrm{~b}$ & $9.171 \mathrm{~b}$ & $9.471 \mathrm{~b}$ & $22.19 \mathrm{a}$ \\
\hline $\mathrm{Mn}$ & $97.00 \mathrm{a}$ & $105.33 \mathrm{a}$ & $105.33 \mathrm{a}$ & $109.33 \mathrm{a}$ & $0.117 \mathrm{~b}$ & $0.092 \mathrm{c}$ & $0.128 b$ & $0.168 \mathrm{a}$ \\
\hline $\mathrm{Zn}$ & $221.33 \mathrm{a}$ & $223.00 \mathrm{a}$ & $199.66 \mathrm{a}$ & $222.00 \mathrm{a}$ & $0.268 b$ & $0.195 \mathrm{c}$ & $0.241 \mathrm{~b}$ & $0.341 \mathrm{a}$ \\
\hline
\end{tabular}

Means followed by the same letters in the rows, within each quadrant, are not different by the Tukey's test $(p<0.05)$ $15 / 60,15 / 30$, and 15/15 minutes = times of exposure of the plants to the nutrient solution (flow/absence of flow) applied through a rectangular 7 meters long PVC tubes with $10 \%$ slope, at flow rate of $1 \mathrm{~L}$ per minute; UF = uninterrupted flow of nutrient solution.

$\mathrm{N}$ and $\mathrm{S}$ are nutrients involved with formation of organic compounds in plants, whereas $\mathrm{Mg}$ is a component of the chlorophyll molecule, among other functions. $\mathrm{Cu}$ is involved with electron transport, and $\mathrm{B}$ is responsible for cell stretching (TAIZ; ZEIGER, 2004). The similar contents found for these nutrients in plants in both treatments indicate that the plants kept an adequate photosynthetic process and, consequently, continued to development, but though at different rates.

Therefore, the higher periodicity of exposure of plants to the nutrient solution in the treatment UF resulted in a higher $\mathrm{N}$ assimilation from nitrate, which partially explains the higher fresh and dry weights found in plants in this treatment. $\mathrm{N}$ is a constituent of amino acids, proteins, enzymes, coenzymes, and nucleotides (MALAVOLTA; VITTI; OLIVEIRA, 1997); in hydroponic systems, it 
is supplied to plants as ammonium and nitrate ions. However, nitrate must be reduced to nitrite in the plant cell cytoplasm and subsequently converted to ammonium in the chloroplasts during the photosynthesis process; but, under water stress conditions, even when moderate, the plant photosynthesis rate decreases (LAWLOR; TEZARA, 2009), favoring accumulation of nitrate in its tissues.

The nitrate and ammonium contents presented inversely proportional results (Table 2). The highest nitrate and lowest ammonium contents were found in plants in the treatment $15 / 30$, and the lowest nitrate and highest ammonium contents in those in the treatment UF. These results indicate occurrence of a higher protein synthesis when using uninterrupted flow of the nutrient solution, which explains the highest growth and fresh and dry weights of lettuce plants in this treatment.

$\mathrm{P}$ is an essential nutrient for reactions involving ATP; $\mathrm{Ca}$ is involved with ATP hydrolysis reactions; $\mathrm{Mn}$ is involved mainly with $\mathrm{O}_{2}$ evolution; and $\mathrm{Zn}$ is a component of the group of elements that participate of electron transport process (TAIZ; ZEIGER, 2004). The highest contents found for these nutrients in plants in the treatment UF are correlated to the highest dry weight gains found in this treatment, indicating a higher plant development, which was increasingly lower in the other treatments as the intervals between pumping periods were increased.

$\mathrm{K}$ is the main cation involved with turgor and electroneutrality of plant cells, and $\mathrm{Fe}$ is present in the cellular respiration process (TAIZ; ZEIGER, 2004); thus, plants subjected to large intervals between pumping periods were expected to need higher contents of these nutrients in their cells.

Regarding the nutrient accumulation in the shoot and root systems of the lettuce plants evaluated (Table 2), UF was again the best treatment, presenting the highest accumulations for all evaluated nutrients in these plant parts. The plants in the treatments $15 / 15$ and $15 / 60$ presented, in general, intermediate results for nutrient accumulation, and those in the treatment $15 / 30$ minutes presented the lowest nutrient accumulation.

The highest $\mathrm{P}, \mathrm{Ca}, \mathrm{Cu}$, and $\mathrm{Fe}$ contents in the plant root system were found in the treatment UF due to the uninterrupted availability of these nutrients in the nutrient solution. However, no significant differences were found for the contents of most nutrients $(\mathrm{N}, \mathrm{K}, \mathrm{Mg}, \mathrm{S}, \mathrm{B}, \mathrm{Mn}$, and $\mathrm{Zn})$ in the different periodicities of nutrient solution flow tested.

The nutrient accumulation in the plant root system, in general, was similar to that found for the plant shoot system. The plants in the treatments UF and $15 / 30$ presented the highest and lowest nutrient accumulations, respectively.

The macro and micronutrients absorption by plants in all treatments evaluated in the present study showed similar order to that established for high lettuce yields: $\mathrm{K}>\mathrm{N}>\mathrm{Ca}>\mathrm{P}>\mathrm{Mg}>\mathrm{S}>\mathrm{Fe}>\mathrm{Zn}>\mathrm{Mn}>\mathrm{B}>\mathrm{Cu} \quad$ (FAQUIN; FURLANI NETO; VILELA, 1996).

The plants in the treatment UF presented the highest nutrient use efficiency (NUE), except for Zn, which presented higher NUE only by plants in the treatment 15/60 (Figure 3).
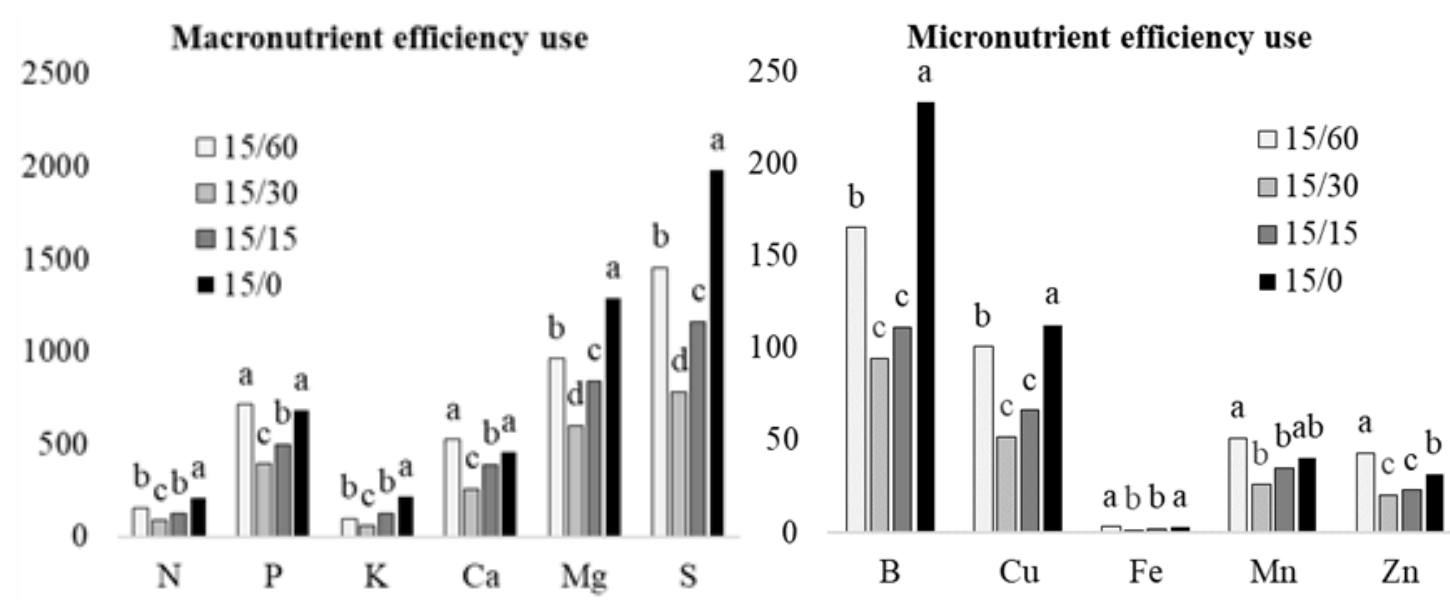

Figure 3. Nutrient use efficiency (NUE) of lettuce plants subjected to different periodicities of exposure to nutrient solution in a hydroponic system.

The NUE decreased for most nutrients in plants according to the following order of treatments: $15 / 60,15 / 15$, and $15 / 30$; the latter presented plants with the lowest NUE for all nutrients evaluated.

Regarding the economic analysis, considering an average lettuce bunch price of BRL (R\$) 2.50, the treatment UF resulted in the highest profits (128\%), followed by the treatments $15 / 60(36 \%)$ and $15 / 15$ $(18 \%)$. The value found in this analysis for plants in the treatment $15 / 30$ was below their production cost, which indicates that this treatment will likely generate direct economic losses if used in a productive system (Table 3). Contrastingly, Luz et al. (2017) found best economic performance for 
plants in the treatment $15 / 60$. This difference may be due to the location (environmental conditions) of that experiment, which was conducted under mild climate conditions, in Santa Maria, RS, Brazil, whereas the present study was conducted under higher temperature and solar radiation conditions; these factors cause different physiological responses in plants because of their transpiration rates.

Table 3. Production cost, and gross and net revenues per lettuce plants subjected to different periodicities of exposure to nutrient solution in a hydroponic system.

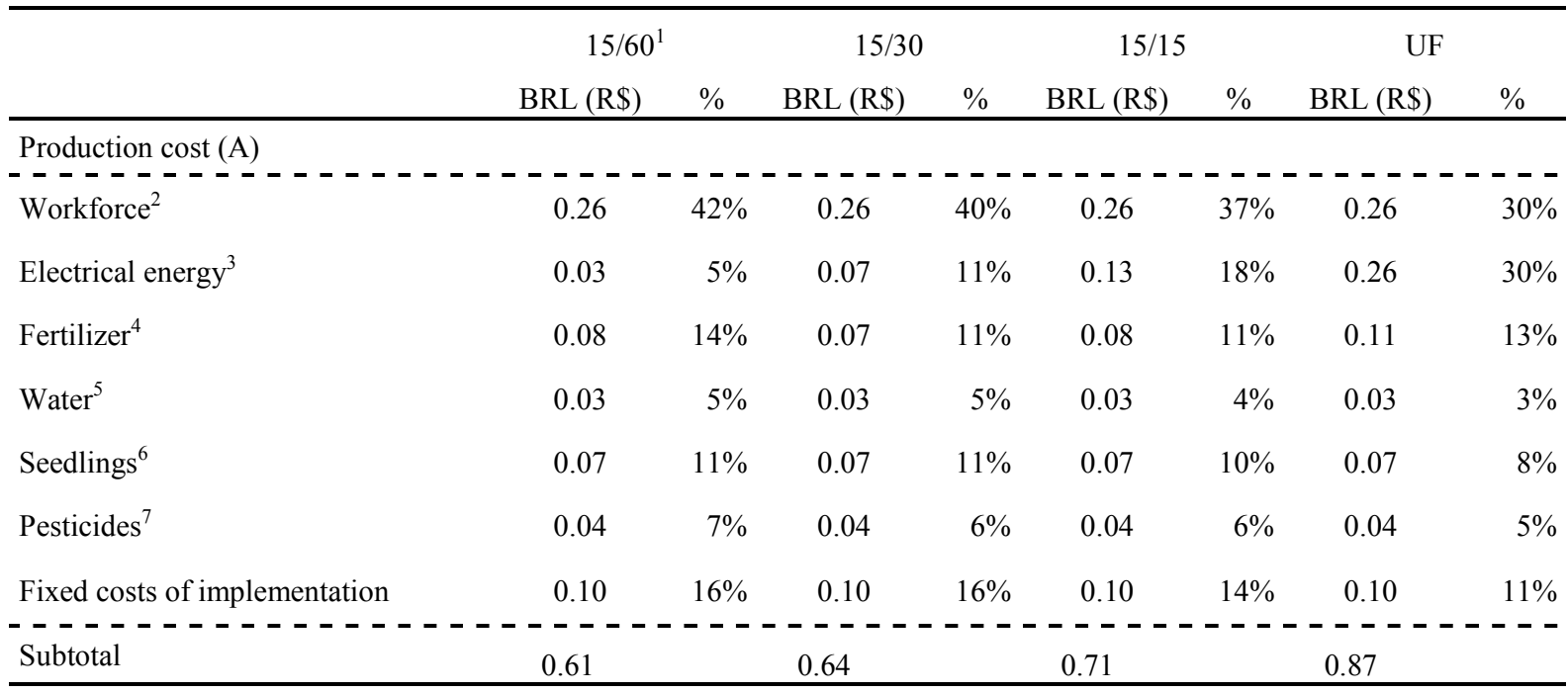

Gross revenue $(\mathrm{B})$

Number of plants per bunch
Subtotal

Subtotal

$0 . \overline{3}$

0.63

Net revenue $(\mathrm{A}-\mathrm{B})$

\begin{tabular}{lcccc} 
& 0.22 & -0.01 & 0.12 & 1.63 \\
\hline \hline Cost-benefit analysis & $136 \%$ & $97 \%$ & $118 \%$ & $287 \%$ \\
\hline
\end{tabular}

${ }^{1} 15 / 60,15 / 30$, and $15 / 15$ minutes $=$ times of exposure of the plants to the nutrient solution (flow/absence of flow) applied through a rectangular 7 meters long PVC tubes with $10 \%$ slope, at flow rate of $1 \mathrm{~L}$ per minute; UF = uninterrupted flow of nutrient solution. ${ }^{2}$ Total workforce cost during the production cycle per plant; ${ }^{3}$ Total electrical energy consumption cost considering an increasing pumping capacity of the nutrition solution in the hydroponic system as the flows are decreased); ${ }^{4}$ Cost of the nutrient solution consumed during the production cycle; ${ }^{5} \mathrm{Cost}$ of the water consumed during the production cycle; ${ }^{6}$ Total cost of the lettuce seedlings grown in phenolic foam, including their maintenance in the nursery; ${ }^{7}$ Cost of application of Difenoconazole and Kasugamycin; ${ }^{8}$ Rent cost of the greenhouse equipped for hydroponics; ${ }^{9}$ Quantity of plants needed to compose a commercial bunch to be sold to wholesalers at a price of BRL (R\$) 2.50 .

A study conducted in Tijucas, Santa Catarina, Brazil, presented a production cost of BRL (R\$) 0.79 per unit, which is a similar value to that found in the present study, and was considered economically profitable and viable for that region (ROVER; BARCELOS-OLIVEIRA; TEIXEIRA, 2014). Leite et al. (2016) estimated a net revenue of BRL (R\$) 0.40 per hydroponic lettuce plant in Matão, São Paulo, Brazil, which is still reasonable for its production in family farms. Therefore, the net revenue of found in the present study for plants in the treatment with uninterrupted nutrient solution flow was higher: BRL (R\$) 1.63.

\section{CONCLUSIONS}

The highest production and profitability of the lettuce plants evaluated were found for those in the treatment with uninterrupted nutrient solution flow, which resulted in plants with higher nutrient accumulations in their shoot and root systems and better nutrient use efficiency.

\section{REFERENCES}

ASSOCIAÇÃO BRASILEIRA DO COMERCIO DE SEMENTES E MUDAS - ABCSEM. Dados do setor. Disponível em: <http://www.abcsem.com.br/ dados-do-setor>. Acesso em: 26 jun. 2017.

BACKES, F. A. A. L. et al. Influência da temperatura do ar e da radiação solar no acúmulo de fitomassa da alface. Revista Brasileira de 
Agrometeorologia, 11: 275-283, 2003.

CARON, B. O. et al. Eficiência de conversão da radiação solar fotossinteticamente ativa interceptada em fitomassa de alface. Revista Brasileira de Agrometeorologia, 11: 261-268, 2003.

CASAROLI, D. et al. Desempenho de onze cultivares de alface em duas formas diferentes de canais de cultivo, no sistema hidropônico. Revista da Faculdade de Zootecnia, Veterinária e Agronomia, 10: 25-33, 2003.

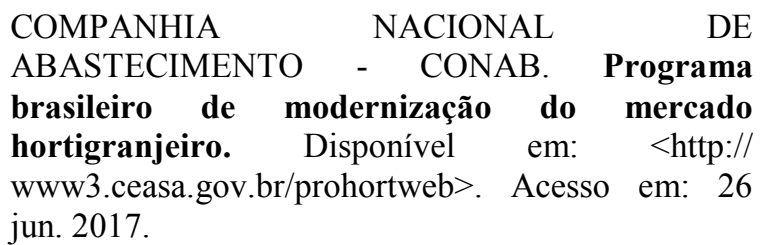

FAQUIN, V.; FURLANI NETO, A. E.; VILELA, L. A. A. Produção de alface em hidroponia. Lavras, MG: UFLA-FAEPE, 1996. 50 p.

HORTICERES. Alface Betty: Cultivo de Verão. 2019. Disponível em: <https:// www.horticeres.com.br/produtos/folhosas/alface/ alface-betty> Acesso em: 30 ago. 2019.

LAWLOR, D. W.; TEZARA, W. Causes of decreased photosynthetic rate and metabolic capacity in water-deficient leaf cells: a critical evaluation of mechanisms and integration of processes. Annals of Botany, 103: 561-579, 2009.

LEITE, D. et al. Viabilidade econômica da implantação do sistema hidropônico para alface com recursos do PRONAF em Matão-SP. Revista iPecege, 2: 57-65, 2016.

LEIVA ESPINOZA, S. T. et al. Comportamiento productivo de 11 variedades de lechuga (Lactuca sativa L.) en sistema hidropónico NFT recirculante (Chachapoyas - Amazonas). Revista de Investigación de Agroproducción Sustentable, 2: 50-56, 2019.

LONDERO, F. A. A.; AITA, A. Comercialização de alface hidropônica. In: SANTOS, O. (Eds.). Hidroponia da alface. 1. ed. Santa Maria, RS: UFSM, 2000. 145-152 p.

LUZ, G. L. et al. Ação dos intervalos entre irrigações no sistema radicular da alface em hidroponia. Interciencia, 42: 370-374, 2017.

LUZ, G. L. et al. Consumo de energia elétrica e produção de alface hidropônica com três intervalos entre irrigações. Ciência Rural, 38: 815-818, 2008.
MALAVOLTA, E.; VITTI, G. C.; OLIVEIRA, S. A. Avaliação do estado nutricional das plantas: princípios e aplicações. 2. ed. Piracicaba, SP: Potafos, 1997. 319 p.

MARTINS, C. M. et al. Curva de absorção de nutrientes em alface hidropônica. Revista Caatinga, 22: $123-128,2009$

MATSUNAGA, M. B.; TOLEDO, P. F. Metodologia de custo de produção utilizada pelo IEA. Agricultura em São Paulo, 23: 123-139, 1976.

MOHAMMED, S. Introduction to Nutrient Film Technique. In: MOHAMMED, S. (Eds.). Tomorrow's Agriculture. 1. ed. Basel, Switzerland: Springer, 2018. p. 7-11.

PAULUS, D. et al. Crescimento, consumo hídrico e composição mineral de alface cultivada em hidroponia com águas salinas. Revista Ceres, 59: 110-117, 2012

PRADO, R. M.; CECÍLIO FILHO, A. B. Nutrição e adubação de hortaliças. Jaboticabal, SP: Funep, 2016. $600 \mathrm{p}$

ROVER, S.; BARCELOS-OLIVEIRA, J. L.; TEIXEIRA, M. P. Viabilidade econômica da implantação de um sistema de cultivo de alface hidropônica em Tijucas-Santa Catarina. In: ENCONTRO BRASILEIRO DE HIDROPONIA, 2, SIMPÓSIO BRASILEIRO DE HIDROPONIA, 3, 2014, Florianópolis. Anais... Florianópolis: UFSC, 2014. p. 93

SIDDIQI, M. Y.; GLASS, A. D. M.. Utilization index: a modified approach to the estimation and comparison of nutrient utilization efficiency in plants. Journal of Plant Nutrition, 4: 289-302, 1981.

TAIZ, L.; ZEIGER, E. Fisiologia vegetal. Porto Alegre, RS: Artmed, 2004. 719 p.

TEDESCO, M. J.; VOLKWEISS, S. J.; BOHNEN, H. Análises de solo, plantas e outros materiais. 1. ed. Porto Alegre, RS: UFRGS, 1985. 95 p. (Boletim Técnico, 5).

TRANI, P.; RAIJ, B. V. Hortaliças. In: RAIJ, B. V. et al. (Eds). Recomendações de adubação e calagem para o estado de São Paulo Campinas, SP: IAC, 1997. p. 157-164. (Boletim técnico, 100). 